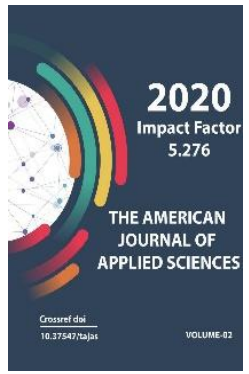

Journal Website: http://usajournalshub.c om/index,php/tajas

Copyright: Original content from this work may be used under the terms of the creative commons attributes 4.0 licence.

\section{Comparative Analysis Of Biocenotic Complexes Of Wheat Nematodes And Wild Cereals}

\author{
Alisher Shukurovich Khurramov \\ Doctor Of Biological Sciences, Associate Professor, Dean Of The Faculty Of Natural Sciences, \\ Termez State University, Termez, Uzbekistan \\ Lobar Abdusamatovna Bobokeldieva \\ Doctoral Student, Department Of Zoology, Faculty Of Natural Sciences, Termez State \\ University, Termez, Uzbekistan
}

\title{
ABSTRACT
}

The article provides a comparative analysis of biocenotic complexes of wheat nematodes and wildgrowing cereal plants. Common methods in phytohelminthology were used to study the fauna of nematodes. As a result of studies in plants and root soil of wheat and wild grasses, 237 species of nematodes were registered. It is noted that on wheat and wild-growing cereals, the common dominant species are P. rigidus, A. avenae, A. parietinus, D. dipsaci. Also, the coefficient of similarity of faunistic complexes of wheat nematodes and wild-growing cereals was studied, and the found nematodes were distributed by ecological groups. It is argued that phytoparasites can transfer to cultivated plants from wild grasses, and also, the data confirm that wild grasses are reserves of parasitic nematodes, and can serve as a hotbed of preservation of nematode invasion for cultivated plants in Uzbekistan.

\section{KEYWORDS}

Biocenotic complexes, ecological groups, similarity coefficient, nematodes, wheat, wild cereals, dominants.

\section{INTRODUCTION}

The increasing demand of the population for the production of grain crops requires an expansion of the area under crops, an increase in plant productivity by intensifying agriculture. However, intensification, being the basis of an intensive agricultural production system, inevitably leads to deterioration in the phytosanitary condition of fields.

Among pests and diseases of plants, one of the main places is occupied by 
phytonematodes, which cause enormous economic damage to agriculture, which is expressed in a significant decrease in yield. In addition, the study of wild plants nematodes growing in and around wheat fields is of great interest for establishing host plants and biotypes. This question is also of interest because many polyphagous parasitic nematodes can easily pass from cultivated plants to wild ones and vice versa. In this sense, plants of wild flora can ensure the preservation of the parasite in nature.

\section{MAIN PART}

Based on the foregoing, the purpose of our phytohelminthological study was to study the fauna and establish the pattern of formation of biocenotic complexes of wheat nematodes and wild-growing cereals in various soil and climatic zones of Uzbekistan.

To elucidate the biocenotic complexes of wheat nematodes and wild-growing cereals, studies were carried out in 2015-2018. in the main grain-growing farms of the regions of Uzbekistan. The selection of soil and plant samples was carried out by the route method [2, p. 3-11]. In total, 2635 samples of soil, root system and aboveground organs of wheat plants of the variety "Grom", "Krasnodarskaya-99" and "Tanya" were collected and analyzed; from wild plants, bulbous bluegrass - Poa bulbosa L., wild barley - Hordeum spontaneum C. Koch ., Louis oats Avena ludoviciana L., intoxicating chaff Lolium temulentum L. and wild rye - Secale sylvestre Host.) growing in and around wheat fields.

To isolate nematodes from soil and plant organs, a modified Berman funnel method was used [2, p. 3-11]. For fixation of nematodes, $4-6 \%$ formalin was used, clearing of nematodes was carried out in a mixture of glycerol with alcohol (1: 3), and glycerol permanent preparations were made for office processing of the material according to the Seinhorst method [4, p. 59-69]. Part of the soil sample was examined for the presence of cyst-forming nematodes according to the standard Decker method [3, p. 221-237].

Anatomical and morphological study of phytonematodes was carried out using temporary and permanent preparations. When determining the species of nematodes, the works of domestic and foreign phytohelminthologists were used, as well as morphometric indicators obtained according to the generally accepted de Mann formula modified according to Mikoletski [5, p. 87].

The degree of dominance of phytonematodes in plant and soil samples was determined by the percentage state of individuals of certain species to the number of all individuals found during research on each culture. Moreover, according to the classification of Crogerus [6, p. 239].

As a result of studies in plants and root soil of wheat and wild-growing cereals, 237 species of nematodes belonging to 2 subclasses, 8 orders, 12 suborders, 16 superfamilies, 36 families, 43 subfamilies and 83 genera were registered.

Registered phytonematode species on wheat and surveyed wild cereals in terms of species composition and number of individuals, the orders Rhabditida, Aphelenchida, Tylenchida, and Dorylaimida are the most numerous. The orders Plectida, Chromadorida, Mononchida, and Enoplida are found in a small number of species and numbers of individuals.

According to the frequency of occurrence of the established species of nematodes in plants and root soil, wheat can be divided between the following groups: dominants - 3 species (Panagrolaimus rigidus, Aphelenchus avenae, Ditylenchus dipsaci), subdominants - 7 species (Chiloplacus propinquus, Rhabditis brevispina, Aphelenchoides parietinus, A. composticola, A. asteromucronatus, Pratylenchus pratensis, Pratylenchoides crenicauda), precedents - 14 species and sub-precedents - 199 species. Of the species found on wild-growing cereals and 
in their root soil, 4 species are dominant (Cephalobus persegnis, Chiloplacus propinquus, Panagrolaimus rigidus, Bitylenchus dubius), 4 species are subdominants (Chiloplacus sclerovaginatus, Aphelenchus avenae, Aphelenchoides parietinus, Ditylenchus dipsaci). The rest of the types are referred to as cases and subcases.

It can be seen from the two lists that wheat and wild plants have common dominant species, such as $P$. rigidus, $A$. avenae, $A$. parietinus, D. dipsaci.

In the ecological analysis of the registered species of plant nematodes, the ecological classification proposed by A.A. Paramonov [1], based on the trophic relationships of nematodes with plants or other soil organisms.

According to ecological groups, registered phytonematodes on wheat and its rhizosphere can be divided between the following groups: pararisobionts - 48 species, eusaprobionts - 15, devisaprobionts - 58, nonspecific parasites -82 , true parasites -20 species.

The types of plant nematodes found on wildgrowing cereal plants are distributed according to ecological groups as follows: pararisobionts - 22 species, eusaprobes - 10, devisaprobes - 29, nonspecific parasites - 35, true parasites - 14 species.
Among ecological groups, in the quantitative ratio of species and in the number of individuals in all studied cereals, representatives of nonspecific parasites prevail, followed by devisaprobes, pararisobionts, and true parasites. Species of plant nematodes from the ecological group of eusaprobes were not numerous in terms of the number of species and the number of individuals.

The study of the fauna of phytonematodes of wild flora is of great interest because many phytonematodes can easily pass from cultivated plants to wild ones and vice versa. In this sense, plants of wild flora can provide for the conservation and accumulation of these roundworms in nature.

The coefficient of similarity between faunistic complexes of wheat nematodes and wildgrowing cereals showed that there is no relationship between them (table).

Pairwise comparison of the species composition of wheat phytonematodes and wild-growing cereals showed that the relationship between the communities of wheat phytonematodes and wild-growing rye was less established. There is no connection between communities of phytonematodes of wheat and wild barley, wheat with bulbous bluegrass, wheat with Louis oats and intoxicating chaff. 
Table

Similarity coefficients and the degree of correlation between the species composition of the community of phytonematodes of wheat and wild-growing cereals

\begin{tabular}{|c|c|c|c|c|c|}
\hline \multirow[b]{2}{*}{ № } & \multirow{2}{*}{$\begin{array}{l}\text { Compared } \\
\text { community }\end{array}$} & \multicolumn{2}{|c|}{$\begin{array}{c}\text { Number of dominant } \\
\text { species }\end{array}$} & \multirow{2}{*}{$\begin{array}{l}\text { Similarity } \\
\text { coefficient }\end{array}$} & \multirow{2}{*}{$\begin{array}{c}\text { Power } \\
\text { connections }\end{array}$} \\
\hline & & $\begin{array}{l}\text { in every } \\
\text { commun } \\
\text { ity }\end{array}$ & $\begin{array}{c}\text { common for the } \\
\text { compared } \\
\text { communities }\end{array}$ & & \\
\hline 1 & $\begin{array}{l}\text { Wheat agrocenosis } \\
\text { Wild barley }\end{array}$ & $\begin{array}{l}28 \\
29\end{array}$ & 11 & 0,39 & Is absent \\
\hline 2 & $\begin{array}{l}\text { Wheat agrocenosis } \\
\text { Bulbous bluegrass }\end{array}$ & $\begin{array}{l}28 \\
28\end{array}$ & 13 & 0,46 & Is absent \\
\hline 3 & $\begin{array}{l}\text { Wheat agrocenosis } \\
\text { Louis oats }\end{array}$ & $\begin{array}{l}28 \\
36\end{array}$ & 12 & 0,37 & Is absent \\
\hline 4 & $\begin{array}{l}\text { Wheat agrocenosis } \\
\text { Wild rye }\end{array}$ & $\begin{array}{l}28 \\
34\end{array}$ & 17 & 0,54 & Weak \\
\hline 5 & $\begin{array}{l}\text { Wheat agrocenosis } \\
\text { Intoxicating spit }\end{array}$ & $\begin{array}{l}28 \\
31\end{array}$ & 10 & 0,34 & Is absent \\
\hline
\end{tabular}

After analyzing the similarity coefficient of real parasites for comparable plants, 13 species (Tylenchorhynchus brassicae, T. tener, T. brevidens, Bitylenchus dubius, Rotylenchus goodeyi, Helicotylenchus dihystera, $\mathrm{H}$. erythrinae, $\quad H$. pseudorobustus, $H$. multicinctus, Pratylenchus pratensis, $\mathrm{P}$. neglectus, P. penetrans, P. coffeae, Pratylenchoides crenicauda, Paratylenchus macrophallus $и$ Ditylenchus dipsaci) were common, among which Bitylenchus dubius, Rotylenchus goodeyi, Helicotylenchus dihystera, Pratylenchus pratensis and Ditylenchus dipsaci prevailed in terms of the number of individuals in all studied cultures.

The presence of a certain similarity in the species composition of phytoparasites between the compared cultures is a direct evidence of the interpenetration of phytonematode species during the formation of their faunistic complexes. 


\section{CONCLUSION}

We have every reason to assert that phytoparasites can pass to cultivated plants from wild cereals. Our data also confirm that wild cereal plants are reserves of parasitic nematodes and can serve as a hotbed of preservation of nematode invasion for cultivated plants in Uzbekistan.

Taking into account the influence of wild cereal plants, as a source, including especially pathogenic species, on cultivated plants, it is necessary to carry out a systematic fight against wild cereals, which can also be considered as a fight against phytohelminths.

\section{REFERENCES}

1. Парамонов А.А. Опыт экологической классификации фитонематод // Тр. ГЕЛАН. - Москва, 1952. Т. 6. С. 338-369.

2. Парамонов А.А. О некоторых принципиальных вопросах фитогельминтологии // Москва,1958. С. 3-11.

3. Decker H. Schädliche Nematodenarten des Getreides und der Gräser. Berlin. 1974.: 221-237.

4. Seinchorst J. W. A rapid method for the transfer of nematodes from fixative to anhydrous glycerin. Nematologica. 1959. V.4.: 57-69.

5. Micoletzky G. Die freilebenden ErdNematoden, mit besonderer Berucksichtigung der Steiermark un der Bukowina, Zugleich mit einer Revision Samtlicher nicht mariner, freilebender Nematoden in Farm von esenus - Beschreibungen und Bestimmungs. Schlusseln. Arch. Naturgesch. 1922. 87.

6. Krogerus R. Oekologische Studien nordis Mootarthropoden. Comment boil. Soc. Sci. Fenn. 1960; 21 (3): 239. 